\title{
Governance and Social Network: Analysis in Cooperatives of Small Citrus Producers in the São Paulo State, Brazil
}

\author{
Leandro Guedes de Aguiar ${ }^{1}$, Giuliana Ap. Santini Pigatto ${ }^{1}$, Sandra Cristina de Oliveira ${ }^{1} \&$ Luiz Fernando Paulillo $^{2}$ \\ ${ }^{1}$ School of Sciences and Engineering, Universidade Estadual Paulista (UNESP), Tupã, Brazil \\ ${ }^{2}$ School of Sciences and Technology, Universidade Federal de São Carlos (UFSCar), São Carlos, Brazil \\ Correspondence: Leandro Guedes de Aguiar, 277 Rio Grande do Norte Street, Bauru, SP., 17013-260, Brazil.
}

Received: November 9, 2020

Accepted: December 14, $2020 \quad$ Available online: December 28, 2020

doi:10.11114/ijsss.v9i1.5074

URL: https://doi.org/10.11114/ijsss.v9i1.5074

\begin{abstract}
The purpose of this paper is to investigate if the network governance structure adopted by small producers' citrus cooperatives has allowed the reduction of risks in transactions, ex-ante (adverse selection) and ex-post (moral hazard), and the problems of opportunism downstream and upstream of the production chain. The planned methodological procedure included the structuring and research of two case studies in cooperatives of small orange producers in the interior of the state of São Paulo, Brazil, comprising a sample of 35 cooperative members surveyed between the two cooperatives analyzed. The analyzes were supported by the Transaction Cost Economics and Social Network approaches. Results indicate the importance of the cooperatives and their network format, as economic agents, in maintaining small producers in the citrus industry activity, allowing the reduction of risks in transactions and the problems of opportunism, downstream and upstream of the chain. It was verified the academic contribution and theoretical reinforcement brought by this study - through the empirical surveys and results produced - to the theory of hybrid governance formats, which lacks empirical support and greater analytical strengthening on the part of the academy, according to its own authors. It is suggested, for future analysis, the use of the network governance approach aimed at strengthening the class of small producers of other agribusiness cultures, also using the theoretical basis belonging to NIE, TCE and Networks. The continuity of analyzes based on relational governance, with institutional and transactional economics as a basis, represents not only academic documentation and support for small rural producers of different cultures, but also the guarantee of theoretical robustness to a structure that is still incipient in historical terms, which finds in Brazilian agribusiness a fertile ground for its development and materialization.
\end{abstract}

Keywords: governance, network, transaction, citriculture, cooperative

\section{Introduction}

\subsection{Introducing the Problem}

Among the various agribusiness production chains that Brazil is competitive in, the orange chain is highlighted, whose leadership began in 1979 and continues to the present day. The country is consolidated as the world's leading orange producer, with a production of 17 million tons in 2017, accounting for twice the production presented by the second-placed, China, which is followed by India, Mexico and the United States (Food and Agriculture Organization of the United Nations [FAO], 2018).

Brazil is the holder of more than $50 \%$ of the world production of orange juice, exporting $97 \%$ of this production and guaranteeing a 76\% share in the world market (Neves et al., 2010; Neves and Trombin, 2017).

According to data from Associação Nacional dos Exportadores de Sucos Cítricos [Citrusbr] (2011), about 65\% of the orange supplied to the industry in Brazil comes from just over 5\% of producers, which showed, in 2011, a large concentration in the supply of fruit. The industry, in turn, owns approximately $35 \%$ of the orchards. Data from Fundo da Defesa da Citricultura [Fundecitrus] (2018), confirm this trend, pointing out that 54\% of the Brazilian citrus belt trees are located in only $3 \%$ of the properties.

Paulillo (2006) and Neves et al. (2010) indicated a concentration trend in the supply of orange, with a decrease in the number of small producers in the citrus industry, while the number of large producers and vertical integration by the industry increased. This is explained by the dynamics of the producer's change of profile, as well as the fact that less 
efficient producers, unable to compete with the more efficient ones, would have left the sector and started to dedicate themselves to another culture, or affiliated to associations and cooperatives, in order to cope with the current scenario of market concentration.

The emergence of associations, cooperatives and orange sales pools in the Brazilian citrus agroindustrial system (AGS) by producers, according to Fiorenzi (1999) and Carvalho (2015) has been decisive in negotiations with the industry, as well as in the disposal of the product to other links in the chain. This has been, perhaps, the only outlet for the maintenance of small and medium citrus farmers in the activity.

According to information obtained from Associação Brasileira de Citricultores (W. Pinto, personal communication, February 10, 2018), small producers who remain active in the citrus agro industrial system are able to remain active mainly due to their membership in associations and cooperatives, in order to increase their representativeness towards the sector and provide alternative governance options.

Thus, the Brazilian citrus AGS has been receiving in-depth research by the academy, highlighting as main themes the conflicting relations present between orange producers and juice processing companies, as well as the particularities present in their coordination modes. The questions about the governance used by different links of the Brazilian citrus chain find in the literature of the New Institutional Economy (NIE) the necessary understanding to different transaction and market movements, such as marketing relationships between downstream and upstream actors, and forms of negotiation.

The NIE literature begins with the works of Ronald Coase (1937) breaking with the neoclassical theory of perfect competition and price as the only means of regulating markets, and establishing the concept of transaction (Note 1) as the basic unit of analysis. This works in an interaction environment where the behavioral assumptions of opportunism and information asymmetry (bounded rationality), as possible cost generators in transactions, are considered. Later on, an important NIE' theoretical arm is established, with Transaction Cost Economics (TCE) being responsible for the studies of the forms of coordination among economic agents.

The works of Coleman (1990), Williamson (1993) and Ambrozini and Martinelli (2017) highlight the problem of decision risk in an environment of uncertainty, both in the negotiations that precede a contract (ex-ante) and those that follow it (ex -post), resulting in problems such as adverse selection and moral hazard, respectively. According to the authors, those problems are results from the opportunistic behaviors, and characteristics such as trust and reputation among agents gain space.

Ménard (2013) highlights cooperatives as an important category of analysis, given the variety of formats and characteristics found in this group, ranging from nearly integrated firms to market arrangement lines, sharing, for the most part, hybrid features in relation to shared rights allocation and modes of governance. According to the author, it is characterized by a theoretically orphaned field, where a greater number of empirical studies and publications by the academic class are necessary.

For the question concerning the increase in the number of small citrus growers in cooperatives, in order to address the difficulties of the market, the social network theory can also be highlighted for analysis. According to Powell (1990), the social network is characterized by reciprocal patterns of communication and social exchange, and guided by factors such as relationship, mutual interest, and reputation among its agents.

Thus, considering the above scenario regarding the current situation of the small producer in the citrus AGS, as well as some considerations about the literature of NIE, TCE and Networks, the research problem is expressed: Does the network governance structure adopted by small producers' citrus cooperatives allow the reduction of risks in transactions, ex-ante (adverse selection) and ex-post (moral hazard), and the problems of opportunism downstream and upstream of the production chain?

In this sense, the general objective of this research is to analyze whether the network governance structure adopted by small producers' citrus cooperatives has allowed the reduction of risks in transactions, ex-ante (adverse selection) and ex-post (moral hazard) and the problems of opportunism downstream and upstream of the production chain. As specific objectives can be cited: (i) verify the hybrid governance structures adopted by cooperatives, regarding the characteristics of transactions and agents (producer-cooperative relationship); (ii) describe the structural and relationship characteristics (as a network) cooperatives in order to take into account the risks of transactions and the problems of adverse selection and moral hazard of agents (producer-cooperative relationship); (iii) analyze, in a comparative way, the governance structures, the network format and the reduction of risks and opportunism of the researched citrus cooperatives.

This research is justified by the need for understanding around the themes of governance and social network with regard to small producers, given the current scenario of drop in the number of small producers in the citrus AGS, as well as its 
membership of associations and cooperatives aiming at increasing competitiveness and reducing market uncertainties. In addition, it aims to contribute scientifically and in an interdisciplinary way, by addressing economic and social issues in the field of cooperatives, which can serve as a reference to other cooperatives in the citrus sector and other sectors.

\subsection{Theoretical Background}

\subsubsection{The New Institutional Economy and the Transaction Cost Economics}

Regarding the contributions of the NIE, two main approaches in the literature can be highlighted: the analysis of the institutional environment, with its formal and informal rules, in which the work of Douglas North (1991) gain relevance; and the analysis of governance structures, as forms of coordination of agents in order to minimize transaction costs, in which the works of Oliver Williamson $(1979,1985,1991)$ and TCE emerge as reference.

Williamson (1979) presents the three main attributes of the transactions, claiming to be the (i) specificity of the traded assets, the (ii) uncertainty involved in the transaction, and the (iii) frequency with which they occur, along with behavioral assumptions (opportunism and bounded rationality), the main characteristics analyzed by the actors for the selection of the appropriate governance structure.

The specificity of the traded asset refers specifically to the degree to which an asset can be reorganized for alternative uses without abdicating its value (Williamson, 1991; Tadelis \& Williamson, 2013). The uncertainty, according to Balestrin and Arbage (2007) is related to the agents' lack of knowledge about elements of the economic, institutional and behavioral environment, who end up exerting some kind of influence in the management of business.

Opportunism, as a behavioral assumption, refers to the search for self-interest with avidity, referring to the incomplete or distorted availability of information; linked to efforts to deceive, distort, disguise or otherwise confuse. Opportunism can also lead to situations of information asymmetry, making economic organization more difficult (Williamson, 2012).

According to Paulillo, Neto and Garcia (2016) the manifestation of opportunism both ex-ante, within the scope of adverse selection, and ex-post, through moral hazard, leads to difficulties regarding the negotiation, execution, monitoring and renewal of contracts, generating transaction costs. This costs, according to the author, must be minimized with the selection and application of the most appropriate governance structure, with institutions acting as elements to contain these costs.

Costs before the firm contracts (ex-ante) can be exposed through costs related to the location of customers and suppliers, with the negotiation process, with the establishment of necessary safeguards, with the formalization of the transaction, as well as with teaching to produce what is needed. On the other hand, the costs after contracting the firm (ex-post) may be related to the poor adaptation of the transactions to the agreement, to the negotiations to correct errors, to the establishment and maintenance of governance, as well as to the maintenance of commitments between both parties (Paulillo et al., 2016).

Thus, given the characteristics of transactions and agents, in the literature on Transaction Cost Economics, Williamson $(1979,1991)$ points out the three main governance structures among agents in order to minimize transaction costs, being (i) market: mainly characterized by short-term transactions (spot) of purchase and sale; (ii) hybrid: intermediate format between short-term transactions and hierarchy, with the contractual relationship prevailing between the parties; (iii) hierarchy: the way in which centralization of decisions prevails, being characterized mainly by vertical integration.

According to the work of Ménard (2004) the specific characteristics of hybrid governance are represented by joint commercial agreements between autonomous entities, with mutual adjustment and the sharing of capital, technology, products and services. Ménard (2013) also highlights the sharing of rights and the pooling of resources as factors that benefit the agents' ability to deal with the uncertainties of transactions, as well as a possible motivation for the hybrid choice of governance.

The typology of the hybrid organization is classified by Ménard (2004) in four general subdivisions - reputation, relational network, leadership and formal governance -, having a construct based on the level of monitoring, control and coordination present among these elements. In this definition, the figure of the 'relational network' is presented by Ménard (2004) as being the relationship between partners conceived through formal rules and conventions, taking as an example, the functioning of clubs and cooperatives, where attributes such as the history of the members, complementarity and social connivance emerge as a basis for management between partners.

Achrol (1997) and Ménard (2013) highlight that there is an increasing sense of perception and importance about relationship networks in hybrid governance structures, as well as the immersion of members and the exchanges that occur within these constructs. These constructions, according to the authors, have values often larger than the sum of the parts, and cannot be understood by the singular study of the elements that compose it. 


\subsubsection{Social Networks and the Economic Environment}

Williamson (1991) states that networks can be interpreted as a non-hierarchical hiring relationship, where the effects inherent to the reputation of their members are communicated quickly and accurately, and can be consulted through individual and shared experience. The effect of reputation, according to the author, can act as an inhibitor of opportunistic behavior and transaction costs.

Thus, in the institutional economy agenda, the network is defined as an organizational form that can complement the contract (Williamson's hybrid governance) in the firm's transaction, being viewed through the perspective of a set of economic actors that enter into cooperative agreements among themselves. The correct definition of the rules for allocating decisions and rights is fundamental in these cooperation agreements, being the contractual rules designed to be enforced through the legal framework, or by social mechanisms, such as reputation (Paulillo et al., 2016).

According to Paulillo et al. (2016), due to the fact that in Williamson's institutional agenda of Transaction Cost Economics $(1975,1991,1996)$ trust has always been neglected as an important characteristic in the evaluation of transaction costs - which, according to the author, it is based on the action intentionally calculated by the entrepreneur -, it is necessary to identify a common space between the apparently antagonistic institutional approaches: the economic view, based on the concepts of opportunism and transaction costs as basic theoretical axes (and where reputation is highlighted as a necessary component in the formation of networks), and sociological, supported by the existence of reciprocal and trusting relationships in cooperative arrangements.

In this context, according to the authors, the emergence of more critical approaches in the field of New Institutional Economics - taking as an example the work of Ménard (2004) - which, even while remaining aligned with TCE, highlights the formats governance hybrids, giving greater emphasis to the reasons for their emergence, as well as the mechanisms used in the coordination of these economic transactions, using, for this, sociological approaches, such as the work of Powell, 1990 and his perspective of networks, where factors such as reciprocity and trust are highlighted.

According to Paulillo et al. (2016), the network, as a form of hybrid governance, appears as a more complex model, involving elements such as relationships of trust, reputation, legitimacy and identity, characterized mainly by the social connections between agents, in a structure of interdependence in sharing costs and benefits, maintaining autonomy and the power to participate in decisions for each member. According to Powell, 1990, the network is characterized by reciprocal patterns of communication and social exchange, being guided by factors such as the relationship, mutual interest and reputation among its agents.

Granovetter (2007) highlights the role of concrete personal relationships in network structures as agents that promote trust and inhibit bad faith, in which the dominant preference is given to carrying out transactions with individuals of known reputation, as an integral part of these structures. According to the author, attributes such as trust, reputation and identification among agents are identified as the main social elements that help to reduce opportunism.

Granovetter (1985) and Smelser and Swedberg (1994) highlight the importance of studying social networks as a form of governance in the economy, stating that economic action occurs within a network of social relations that make up the social structure. According to Ménard $(2004,2013)$ trust emerges as an item that could minimize the effects of opportunism and uncertainty in economic relations, and would become operational through recurring transactions (which refer to reputation).

The work of Zylbersztajn (2005) highlights the issue of coordination and cooperation based on the hybrid format of network governance for the Brazilian agroindustrial system, and points out that when considering the complex range of activities managed by farmers in agroindustrial systems, the emergence and establishment of contractual relationships, formal and informal long-term cooperation agreements, supported by reputation or social ties, are highlighted.

In this sense, the literature by Zylbersztajn and Farina (2010) maintains that the theory about network governance is subject to a more robust theoretical development, in order to provide a greater extension in empirical analyzes, in which the themes on the governance mechanism networked with a focus on efficiency, as well as the presence of trust and social immersion in this context, emerge as recurrent elements in this literature, and promising for empirical work.

\section{Method}

The planned methodological procedure comprised the structuring and research of two case studies in cooperatives of small orange producers in the interior of the state of São Paulo, Brazil, located in the municipalities of Bebedouro and Rio Claro, and referred to in this article as C1 and C2, respectively. C1 was founded in 2012 and has 90 cooperative citrus growers, while C2 was founded in 2014 and has seven (7) cooperative citrus growers. This second cooperative focuses on the production of multi cultures other than just orange, which justifies the difference in number of citrus growers cooperated between the two entities. Both cooperatives aim to organize and sell orange production from family farming. 
The planned case study included the application of a form for the manager of the cooperatives, followed by direct observation guided by the questions asked, and the application of forms with the members, following the sample size obtained for each cooperative considered, having as based on convenience sampling for the selection of respondent members. The preparation of the forms took into account, mostly and when applicable, the use of the Likert scale of three numerical points, in order to make the analysis of the correlation between the researched variables feasible.

The research subjects were the cooperatives members and representatives of the two cooperatives analyzed, using inferential statistics techniques for the collection and general analysis of the data, starting with a statistical procedure to determine the sample size for qualitative variables of a finite population, in order to select the exact number of cooperative members participating in the survey.

A 95\% confidence level was defined for this research, considering a population of $\mathrm{N}=90$ for $\mathrm{C} 1$ and $\mathrm{N}=7$ for $\mathrm{C} 2$, and a margin of error of $15 \%$, a sample (n) of 29 members was obtained for $\mathrm{C} 1$ and 6 (six) members for $\mathrm{C} 2$. The forms directed to the cooperatives members had a total of 35 questions related to the general characteristics of the rural property, the related orange transaction and the network format between the farmer and the cooperative. The application of the forms and direct observations occurred in June 2019.

Classical elements belonging to the theory of TCE were analyzed in the forms, such as the governance structure used and the attributes of transactions (frequency, uncertainty and specificity of assets), under the assumptions of opportunism and limited rationality (ex-ante and ex-post risks involved in the negotiation), considering the transactions and relational aspects of the cooperatives and their citrus growers cooperative as an object of analysis.

The general parameters used by this research regarding the levels of analysis in relation to the characteristics of the transaction and the agents - adopted for both analyzes of the selected cooperatives - is presented in the sequence.

\begin{tabular}{|c|c|c|c|}
\hline & Low & Medium & High \\
\hline Asset specificity & $\begin{array}{l}\text { Use of simple planting and } \\
\text { harvesting. }\end{array}$ & $\begin{array}{l}\text { Use of land preparation, } \\
\text { implements, fertilizers and } \\
\text { systems in general. }\end{array}$ & $\begin{array}{l}\text { Use of land preparation, } \\
\text { implements, fertilizers and specific } \\
\text { / exclusive systems. }\end{array}$ \\
\hline Uncertainty & $\begin{array}{l}\text { High knowledge about the economic } \\
\text { (supply, demand and price of } \\
\text { oranges), institutional (cooperative } \\
\text { bylaws, current rules and laws) and } \\
\text { behavioral environment. }\end{array}$ & $\begin{array}{l}\text { Average knowledge about the } \\
\text { economic (supply, demand and } \\
\text { price of orange), institutional } \\
\text { (social status of the cooperative } \\
\text { bylaws, current rules and laws) } \\
\text { and behavioral environment. }\end{array}$ & $\begin{array}{l}\text { Low knowledge about the } \\
\text { economic (supply, demand and } \\
\text { price of orange), institutional } \\
\text { (cooperative bylaws, current rules } \\
\text { and laws) and behavioral } \\
\text { environment. }\end{array}$ \\
\hline Frequency & $\begin{array}{l}\text { Sporadic and non-regular supplies } \\
\text { (eg spot, punctual) }\end{array}$ & $\begin{array}{l}\text { Interval supplies and with certain } \\
\text { regularity (ex: alternating } \\
\text { harvests) }\end{array}$ & $\begin{array}{l}\text { Regular supplies } \quad \text { (ex: every } \\
\text { harvest) }\end{array}$ \\
\hline Opportunism & $\begin{array}{l}\text { Low frequency of use of self-interest } \\
\text { (distortions of market information } \\
\text { and breach of contract) by the } \\
\text { principal. }\end{array}$ & $\begin{array}{l}\text { Median frequency of use of } \\
\text { self-interest (distortions of } \\
\text { market information and breach } \\
\text { of contract) by the principal. }\end{array}$ & $\begin{array}{l}\text { High frequency of use of } \\
\text { self-interest (distortions of market } \\
\text { information and breach of contract) } \\
\text { by the principal. }\end{array}$ \\
\hline $\begin{array}{l}\text { Bounded } \\
\text { rationality }\end{array}$ & $\begin{array}{l}\text { High frequency of use of market } \\
\text { (price, supply and demand for } \\
\text { orange) and managerial information } \\
\text { (costs, inventory, technology). }\end{array}$ & $\begin{array}{l}\text { Median frequency of use of } \\
\text { market (price, supply and } \\
\text { demand for orange) and } \\
\text { managerial information (costs, } \\
\text { inventory, technology). }\end{array}$ & $\begin{array}{l}\text { Low frequency of use of market } \\
\text { (price, supply and demand for } \\
\text { orange) and managerial } \\
\text { information (costs, inventory, } \\
\text { technology). }\end{array}$ \\
\hline
\end{tabular}

Figure 1. Parameters of the levels of analysis in relation to the characteristics of the transaction and the agents for the selected cases

Source: Elaborated by the authors from Williamson (1991, 2012), Balestrin and Arbage (2007) and Tadelis and Williamson (2013).

The next Figure presents the general parameters used in terms of the levels of analysis in relation to the structural characteristics of the Network, also adopted for both analyzes of the selected cooperatives. 


\begin{tabular}{|c|c|c|c|}
\hline & Low & Medium & High \\
\hline Trust & $\begin{array}{l}\text { Low incidence of concrete } \\
\text { personal relationships, } \\
\text { convergence of expectations } \\
\text { and development of } \\
\text { common language. }\end{array}$ & $\begin{array}{l}\text { Median incidence of } \\
\text { concrete personal } \\
\text { relationships, convergence } \\
\text { of expectations and } \\
\text { development of common } \\
\text { language. }\end{array}$ & $\begin{array}{l}\text { High incidence of concrete personal } \\
\text { relationships, convergence of } \\
\text { expectations and development of } \\
\text { common language. }\end{array}$ \\
\hline Reputation & $\begin{array}{l}\text { Low knowledge about the } \\
\text { history, experience and } \\
\text { reciprocity between the } \\
\text { parties. }\end{array}$ & $\begin{array}{l}\text { Average knowledge about } \\
\text { the history, experience and } \\
\text { reciprocity between the } \\
\text { parties. }\end{array}$ & $\begin{array}{l}\text { High knowledge about the history, } \\
\text { experience and reciprocity between the } \\
\text { parties. }\end{array}$ \\
\hline Social ties & $\begin{array}{l}\text { Low frequency of } \\
\text { relationships, social } \\
\text { exchange and trust between } \\
\text { the parties. }\end{array}$ & $\begin{array}{l}\text { Median relationship } \\
\text { frequency, social exchange } \\
\text { and trust between the } \\
\text { parties. }\end{array}$ & $\begin{array}{l}\text { High frequency of relationships, social } \\
\text { exchange and trust between the parties. }\end{array}$ \\
\hline Identity & $\begin{array}{l}\text { Low frequency about the } \\
\text { communion of goals and } \\
\text { social relationships. }\end{array}$ & $\begin{array}{l}\text { Median frequency about the } \\
\text { communion of goals and } \\
\text { social relations. }\end{array}$ & $\begin{array}{l}\text { High frequency about the communion } \\
\text { of goals and social relationships. }\end{array}$ \\
\hline
\end{tabular}

Figure 2. Parameters of the levels of analysis in relation to the characteristics of the transaction and the agents for the selected cases

Source: Elaborated by the authors from Granovetter (1985, 2007), Powell (1990), Williamson (1991), Jones, Hersterly, \& Borgatti (1997), Sako and Helper (1998), Ménard (2004), Capra (2008) and Paulillo et al. (2016).

The results were analyzed in a qualitative way, with the characteristic description referring to direct observation and the use of descriptive and inferential statistics, in order to assist in dealing with the organization, tabulation and description of the data set collected in the form of forms. Correlation analyzes were also used for data analysis, considering the correlation between variables collected in the two analyzed cooperatives.

Spearman rank correlation analysis was used in order to analyze the association between the variables surveyed in both cooperatives. According to Martins and Domingues (2011) the Spearman rank correlation coefficient (rs) is a measure of the intensity of the correlation between two variables with ordinals measurements levels, arranged between two sets of posts. The BioEstat 5.0 software was used to calculate the correlation coefficient for Spearman posts, as well as other items related to descriptive statistics, as needed.

In a conclusive way, obtaining the value of the Spearman correlation coefficient (rs) reflects, in numerical values, the degree of association between the variables under study, being able to move in a space of variation between -1 (inversely correlated variables), 0 (uncorrelated variables) and 1 (directly correlated variables).

\section{Results and Discussion}

\subsection{Evidences of Reduction of Risks in Transactions and Problems of Opportunism in Small Producers' Citrus Cooperatives}

The main product sold by $\mathrm{C} 1$ in 2019 was fresh orange, which accounted for $100 \%$ of the entity's sales market share, being sold entirely at regional level to a juice processing company, through direct delivery of the cooperative property to the processor and under the negotiation of the cooperative. In the same way, the main product sold by $\mathrm{C} 2$ in 2019 was fresh orange, being sold entirely at regional level to the city hall of Rio Claro (SP), through direct delivery of the cooperative's product to municipal schools in the region, for use in school meals.

The main objective of $\mathrm{C} 1$ is the organization and commercialization of orange production from family farming, through training, development and adaptation of family farmers to business agriculture, adding value and differentiating the products produced by cooperative citrus growers (mainly through obtaining seals and certifications), as well as creating an own brand. 
According to the entity's vice president, the cooperative had 170 members in 2019, 90 of which are dedicated to the practice of citrus and 80 dedicated to other cultures. The profile of the share of citrus growers associated with $\mathrm{C} 1$, is classified as small producers who own one (1) property and have been in the citrus industry for more than 40 years. This portion of producers considers the citrus industry activity unstable for small producers, mainly due to the low prices practiced by the market, finding in the cooperativism a way of survival in the orange AGS.

For strategic reasons related to market and brand positioning, as of 2017, C1 chose to focus its sales based only on Fairtrade (Note 2) certification market.

Among the main objectives of the $\mathrm{C} 2$ cooperative, the incentive to family farming and the promotion of the sale and economic-social inclusion of the cooperative by guaranteeing the sale of part of its product at a fair price is highlighted. The reasons for family farmers to cooperate with $\mathrm{C} 2$ include the commercialization of their production, through the possibility of their participation in public policy programs for the supply of products, as well as the possibility of industrialization and adding value to this production (as the use of vacuum packaging)

C2 had 130 cooperative members in 2019, seven (7) dedicated to the practice of citrus farming, with the profile of the share of associated citrus growers classified as small producers who own one (1) property and who have been involved in citrus farming for more than 40 years. This share of producers, as in the case of $\mathrm{C} 1$, also considers the citrus industry activity to be unstable for small producers, mainly due to the incidence of pests and diseases in the crop and low prices practiced by the market, also finding in cooperativism a way of survival in the orange AGS.

Figure 3 shows the graphs of the characteristics of the transaction and of the agents in the sale of the orange from the cooperative members to the cooperatives, considering the data from $\mathrm{C} 1$ and $\mathrm{C} 2$.

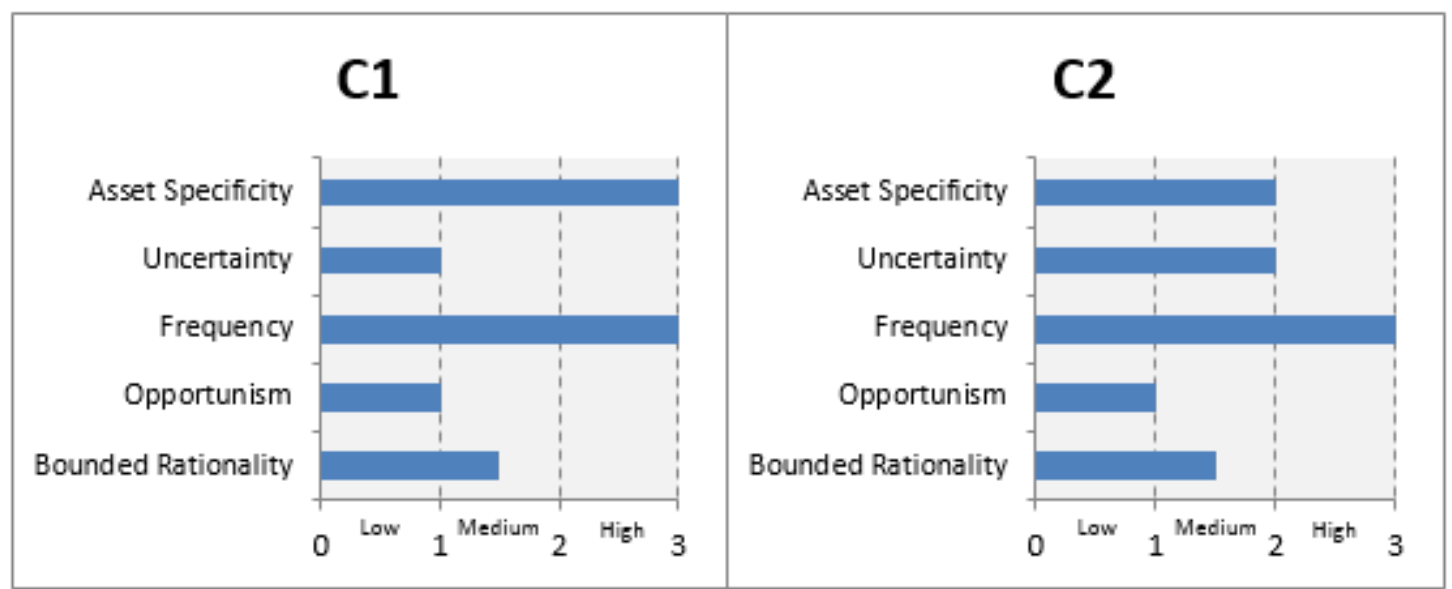

Figure 3. Comparison of the characteristics of the orange transaction between producers and cooperative (C1 and $\mathrm{C} 2)$

Source: Prepared by the authors (2019)

In general, the characteristics of the orange transaction between the cooperative member and the $\mathrm{C} 1$ and $\mathrm{C} 2$ cooperatives differ in points related to the specificity of the transacted asset (in terms of investment grade) and the uncertainty that permeates the transaction, measured by the agents' lack of knowledge, about elements of the economic, institutional and behavioral environment, according to Balestrin and Arbage (2007). In this comparison, the only item of similarity between the two cooperatives analyzed was in relation to the high frequency of supplying the cooperative member orange to the cooperatives.

The characteristics of the agents in the orange transaction, between the cooperative member and the $\mathrm{C} 1$ and $\mathrm{C} 2$ cooperatives, have similarities in the two points related to the low opportunism and the low-medium bounded rationality of the agents in supplying the orange to the cooperatives.

Thus, the contract figure was selected as a regulatory means in both cases, characterizing governance in its hybrid instance. In the case of $\mathrm{C} 1$, the low degree of uncertainty of the transaction reflects the institutional preparation on the part of the cooperative and its spread to the cooperative members class, as well as the prior knowledge of behavioral attributes on the part of the agents who transact, positively relating to the low opportunism and ex-ante and ex-post risks of this economic relationship. In the case of $\mathrm{C} 2$, the median degree of uncertainty in the marketing of oranges is reinforced mainly by the multicultural management of the cooperative and by the time of relationship between the 
agents, which exposes a management based on the knowledge of diverse and representative cultures to the cooperative, which not only the orange.

In this sense, hybrid governance seems to play its role of transactional coordination well, minimizing opportunism in relations and ensuring coordination and commercialization for small fruit producers, in both cases.

The items referring to the characteristics of network governance in the orange transaction between the cooperative members and the $\mathrm{C} 1$ and $\mathrm{C} 2$ cooperatives are presented through Figure 4.

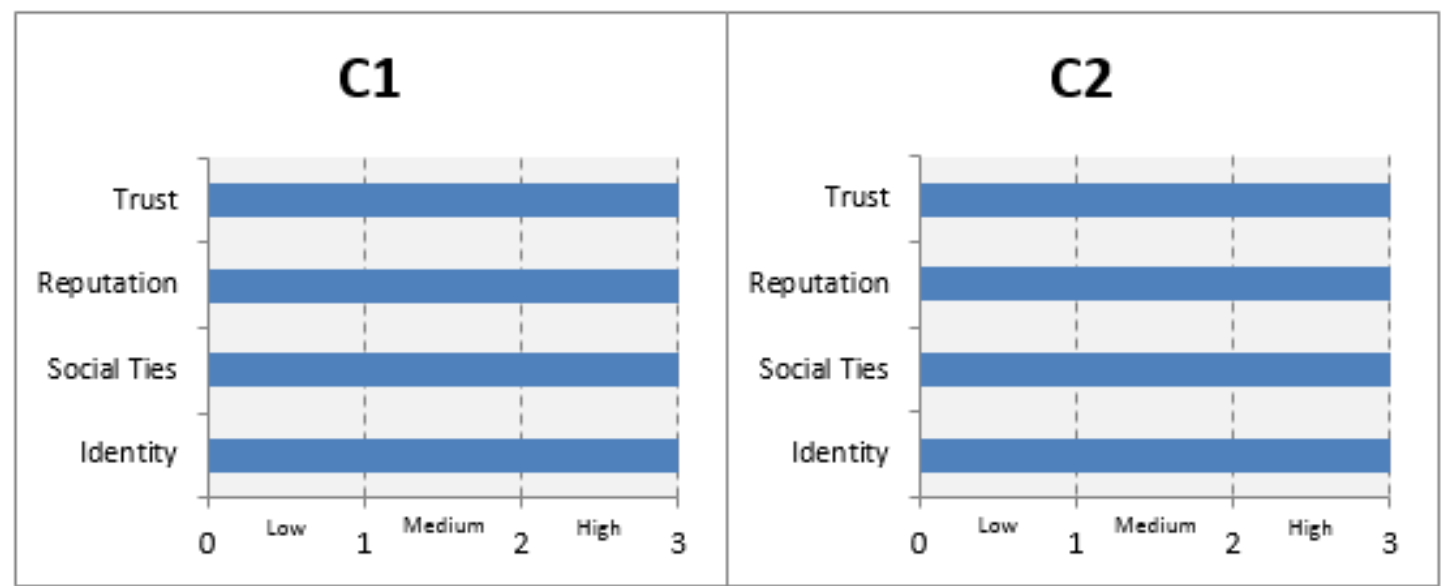

Figure 4. Comparison of the characteristics of network governance in the orange transaction between producers and cooperative ( $\mathrm{C} 1$ and $\mathrm{C} 2)$

Source: Prepared by the authors (2019)

Component elements of network governance, according to Powell (1990) and Paulillo et al. (2016) such as trust, reputation, social ties and identity were classified as being of high intensity in the orange transaction between the cooperative members and the cooperatives $\mathrm{C} 1$ and $\mathrm{C} 2$. As previously highlighted, both relationships are also constituted by the interdependence and mutual interests between cooperative and cooperative members, showing the similarity regarding the characteristics of network governance in the two cases studied.

In this sense, the adoption of a more horizontal model to govern the transaction meets the needs and desires of the agents who transact, since both the class of members and the cooperatives themselves are composed of small citrus growers from an unsustainable model for maintenance of the producing class in the orange AGS. Thus, network governance emerges as a mechanism that provides elements that guarantee the representativeness and confidence necessary for the class of small fruit producers, as economic agents and part of an agro-industrial system.

In the specific case of $\mathrm{C} 2$, a preference was observed for the adoption of informal verbal contracts in the orange transaction between producer and cooperative, highlighting the importance and the high level of trust that exists between the parties that transact.

The hybrid network governance adopted by the agents, as part of a cooperative, once again demonstrates its efficiency in guaranteeing a high level of trust and identity between the parties, acting assertively in reducing the opportunism and risks arising from this transaction.

In sequence, Figure 3 presents the graphs of ex-ante and ex-post costs in the sale of orange from the small producer to the cooperative and to the industry, considering the data from $\mathrm{C} 1$ and $\mathrm{C} 2$. 


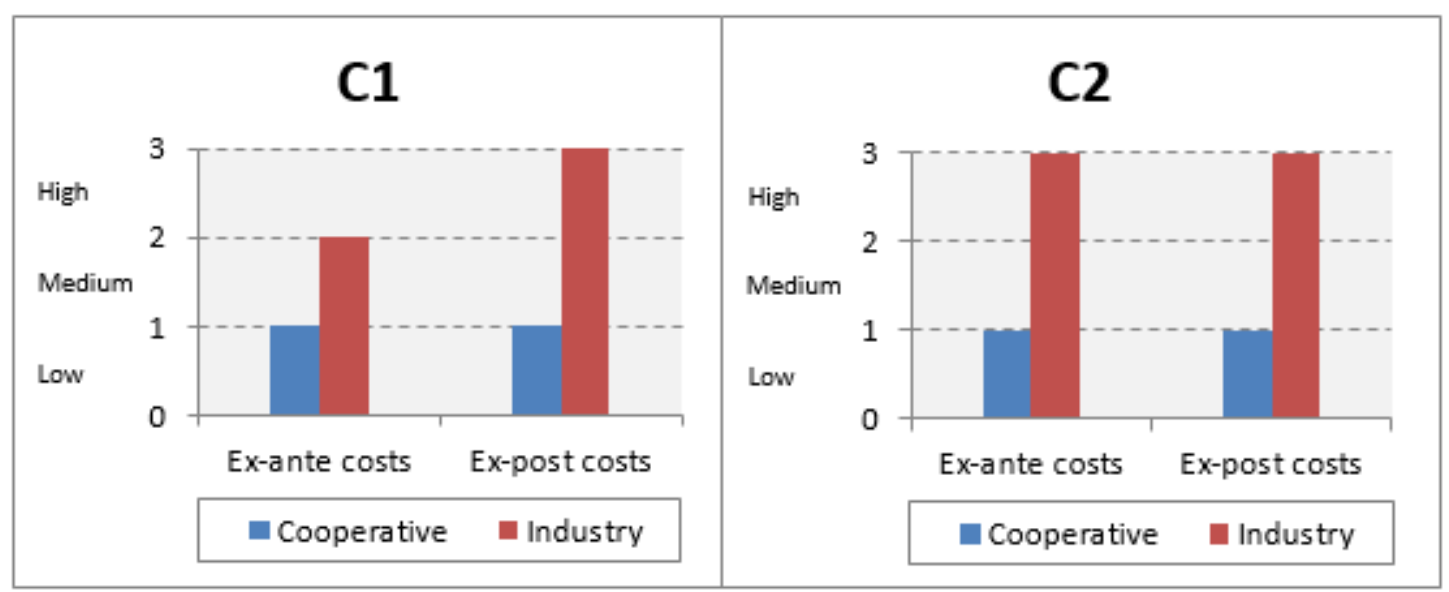

Figure 5. Comparison of ex-ante and ex-post costs in the sale of orange from the small producer to the cooperative and to the industry $(\mathrm{C} 1$ and $\mathrm{C} 2)$

Source: Prepared by the authors (2019).

In general, the comparison between ex-ante and ex-post costs of selling smallholder oranges to the cooperative and the industry, considering the research carried out at $\mathrm{C} 1$ and $\mathrm{C} 2$, shows similarity in terms of low cost ex-ante and ex-post sale of the cooperative members' orange to the cooperatives, as well as the high ex-post cost when the cooperative members' orange is sold to the industry. In this comparison, the only item of divergence between the two cooperatives analyzed was in relation to the ex-ante costs of selling the cooperative members' orange to the industry, measured by costs related to negotiation and contractual structuring, according to Paulillo et al. (2016).

Through direct observation and the answers provided in the forms, it was observed that this difference is mainly due to the fact that the sale of orange in $\mathrm{C} 1$ occurs directly with the processing industry. In this scenario, the cooperative members figure as the main responsible for the delivery and direct contact with the processing industry, giving that class prior knowledge based on the good commercial relationship, as already mentioned, between cooperative and industry, and influencing the opinion of producers about the intensity negotiation and contractual structuring costs with the processing industry.

The sale of oranges at $\mathrm{C} 2$, in turn, involves the delivery of the product owned by the cooperative member to the cooperative's headquarters for later conference and distribution to the municipal schools of Rio Claro (SP), without involving any commercial contact with the processing industry, influencing in the opinion of the producers about the intensity of the costs of negotiation and contractual structuring with that class.

For conducting the correlation analysis, 16 key questions from the form applied to the members of the two cooperatives were based, with ten (10) questions related to the characteristics of the transaction and the agents (18.1 to 25) and six (6) questions related to the characteristics of network governance (29 to 35). The level of significance was set at $0.05(\alpha=$ $5 \%$ ), and all questions considered containing the three-point Likert scale.

The comparative graphical analysis of the questions considered between $\mathrm{C} 1$ and $\mathrm{C} 2$, as well as the correlation index obtained through the BioEstat 5.0 software, considering the exposed scenario, is presented through Figure 6. 


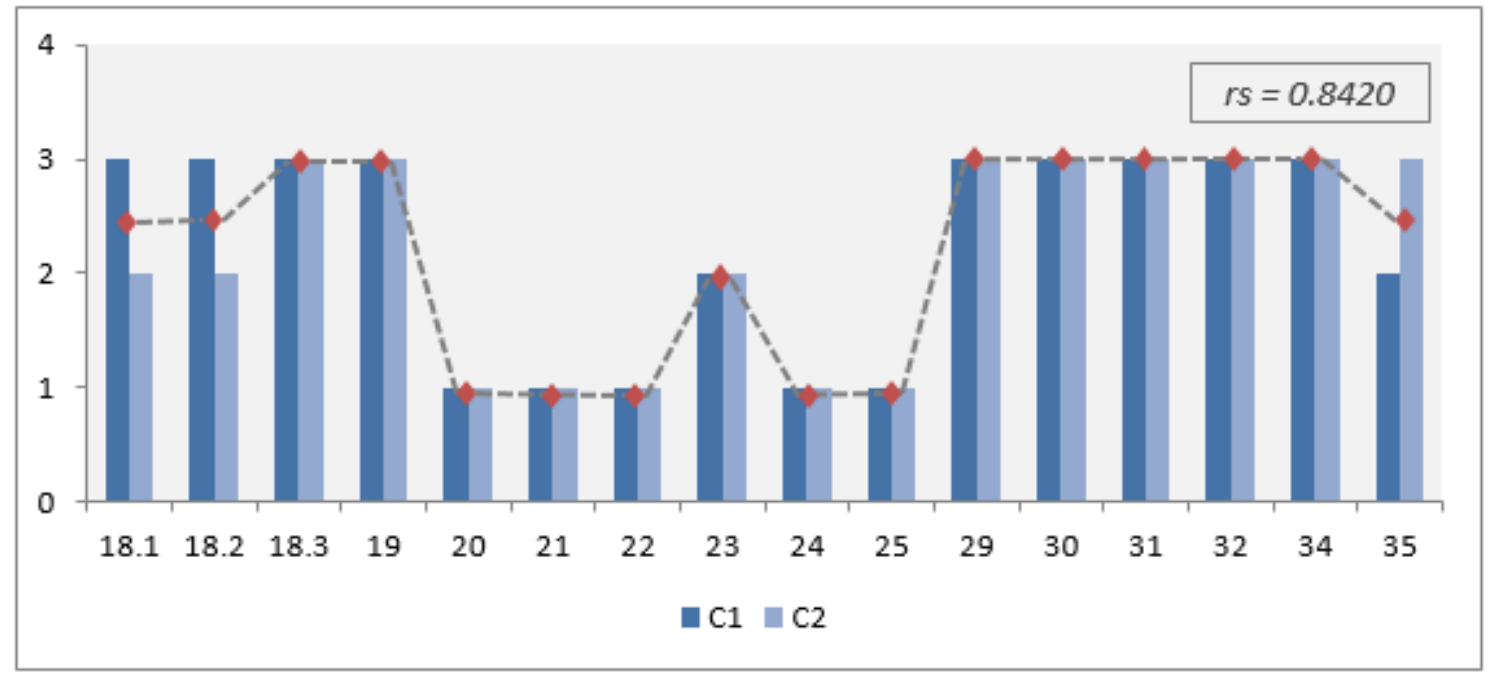

Figure 6. Comparison of responses related to the characteristics of transactions, agents and network governance between $\mathrm{C} 1$ and $\mathrm{C} 2$, and the result of the correlation coefficient by Spearman posts (rs)

Source: Prepared by the authors (2019)

With the entry into the BioEstat 5.0 software of the answers to the 16 key questions related to the characteristics of transactions, agents and network governance, directed to $\mathrm{C} 1$ and $\mathrm{C} 2$, a correlation coefficient was obtained by Spearman posts (rs) of 0.8420 .

Thus, it is concluded that the characteristics of transactions, agents and network governance between the two cooperatives surveyed are correlated, presenting a correlation coefficient of $84 \%$, which demonstrates a strong agreement for these characteristics, between institutions $\mathrm{C} 1$ and $\mathrm{C} 2$.

\subsection{Concluding Remarks}

The analysis of the two citrus cooperatives of small producers, under the perspective of NIE, TCE and Networks, brought to the fore the relational approach as a way of coping with recent market movements observed in the most different cultures of Brazilian agribusiness. Through empirical surveys and analyzes based on qualitative and quantitative approaches, it was possible to affirm that the network governance brought representativeness and perpetuity to a class of producers that until then had the continuity of their activities uncertain in the Brazilian orange AGS. In both cases, there was a reduction in the risks of selling the orange from the small producer, as part of a cooperative, as well as a reduction in the agents' opportunism, considering this same scenario.

Thus, as a conclusive part of this article, it can be stated as an answer to the main research question, that the network governance structure worked by citrus cooperatives of small producers has allowed the reduction of risks in transactions and the problems of opportunism downstream and upstream of the production chain. It is also characterized, the contribution and theoretical reinforcement brought by this study to the theory of hybrid governance formats, which lacks empirical support and greater analytical strengthening on the part of the academy, according to its own authors.

One of the main limitations of this research is the possible disparity in the understanding, by the respondents of it, of terms present in the sociological literature such as trust and reputation. The possibility of relativization and difference in the interpretation of the words used in this study are reinforced by a gap still under construction and the lack of a robust literature on the part of the NIE elucidating this specific approach.

It is suggested, for future analysis, the use of the network governance approach aimed at strengthening the class of small producers of other agribusiness cultures, also using the theoretical basis belonging to NIE, TCE and Networks. The continuity of analyzes based on relational governance, with institutional and transactional economics as a basis, represents not only academic documentation and support for small rural producers of different cultures, but also the guarantee of theoretical robustness to a structure that is still incipient in historical terms, which finds in Brazilian agribusiness a fertile ground for its development and materialization.

\section{Acknowledgements}

This paper was made possible through the financial support provided by the São Paulo Research Foundation (FAPESP). Grant \#2018/12221-5, São Paulo Research Foundation (FAPESP). The opinions, hypotheses and conclusions or 
recommendations expressed in this material are the responsibility of the author (s) and do not necessarily reflect the views of FAPESP.

\section{References}

Achrol, R. S. (1997). Changes in the Theory of Interorganizational Relations in Marketing: Toward a Network Paradigm. Journal of the Academy of Marketing Science, 25(1), 56-71. https://doi.org/10.1007/BF02894509

Ambrozini, L. C. S., \& Martinelli, D. P. (2017). Formal and relational contracts between organizations: proposal of a model for analysis of the transactional and governance structure characteristics of comparative cases. Revista de Administração, 52(4), 374-391. https://doi.org/10.1016/j.rausp.2017.08.010

Associação Nacional dos Exportadores de Sucos Cítricos (2011). A Indústria Brasileira de Suco de Laranja. São Paulo, SP: CITRUSBR.

Balestrin, A., \& Arbage, A. P. (2007). A perspectiva dos custos de transação na formação de redes de cooperação. $R A E$ Eletrônica, 6(1), 1-26. https://doi.org/10.1590/S1676-56482007000100008

Capra, F. (2008). Vivendo Redes. in Duarte, F.; Quandt, C.; Souza, Q. (Org.) O Tempo das Redes. São Paulo, SP: Perspectiva.

Carvalho, M. S. (2015). Contratos Formais entre Empresas Processadoras de Laranja e Citricultores: um estudo de múltiplos casos entre os anos-safras de 1978/79 a 2011/12 na perspectiva dos produtores. (Unpublished doctoral dissertation). Federal University of São Carlos, São Carlos, Brazil.

Coase, R. H. (1937). The nature of the firm. Economica, 4(16), 386-405. https://doi.org/10.1111/j.1468-0335.1937.tb00002.x

Coleman, J. S. (1990). Foundations of social theory. Cambridge, MA: Harvard University Press.

Fairtrade International. (2019). Whait is Fairtrade?. Retrieved July 10, 2019, from https://www.fairtrade.net/about-fairtrade/what-is-fairtrade.html.

Fiorenzi, A. A. (1999). Pedras no caminho. AgroANALYSIS, 19(5), 33-37.

Food and Agriculture Organization of the United Nations. (2018). FAOSTAT. Retrieved Jan 25, 2019, from http://www.fao.org/faostat/en/\#rankings/countries_by_commodity

Fundo da Defesa da Citricultura. (2018). Inventário de árvores e estimativa da safra de laranja do cinturão citrícola de São Paulo e Triângulo/Sudoeste Mineiro 2018/19. São Paulo, SP: Fundecitrus. Retrieved from https://www.fundecitrus.com.br/pdf/pes_relatorios/2018_05_21_Invent\%C3\%A1rio_e_Estimativa_do_Cinturao_C itricola_2018-20191.pdf

Granovetter, M. (1985). Economic Action and Social Structure: The Problem of Embeddedness. American Journal of Sociology, 91(3), 481-510. https://doi.org/10.1086/228311

Granovetter, M. (2007). Ação econômica e estrutura social: o problema da imersão. RAE-eletrônica, 6(1), 1-41. https://doi.org/10.1590/S1676-56482007000100006

Jones, C., Hesterly, W. S., \& Borgatti, S. P. (1997). A general theory of network governance: Exchange conditions and social mechanisms. Academy of Management Review, 22(4), 911-945. https://doi.org/10.5465/amr.1997.9711022109

Martins, G. A., \& Domingues, O. (2011). Estatística geral e aplicada. São Paulo, SP: Atlas.

Ménard, C. (2004). The economics of hybrid organizations. Journal of Institutional and Theoretical Economics, 160(3), 345-376. https://doi.org/10.1628/0932456041960605

Ménard, C. (2013). Hybrid Modes of Organization: alliances, joint ventures, networks, and other 'strange' animals. In Gibbons, R.; Roberts, J. (Ed.), The Handbook of Organizational Economics. Princeton: Princeton University Press. https://doi.org/10.1515/9781400845354-028

Neves, M. F., \& Trombin, V. G. (2017). Anuário da Citricultura 2017. São Paulo, SP: CitrusBR.

Neves, M. F., Trombin, V. G., Milan, P., Lopes, F. F., Cressoni, F., \& Kalaki, R. (2010). O retrato da citricultura brasileira. Ribeirão Preto, SP: CitrusBR.

North, D. C. (1991). Institutions. Journal of Economic Perspectives, 5(1), 97-112. https://doi.org/10.1257/jep.5.1.97

Paulillo, L. F. (2006). Agroindústria e citricultura no Brasil: diferenças e dominâncias. Rio de Janeiro, RJ: E-papers.

Paulillo, L. F., Neto, M. S., \& Garcia, L. M. (2016). Governanças de redes: economia, política e sociedade. Rio de 
Janeiro, RJ: Elsevier.

Powell, W. W. (1990). Neither market nor hierarchy: network forms of organization. In Staw, B. M., \& Cummings, L. L. (Ed.), Research in Organization Behavior. London, UK: JAI Press Inc.

Sako, M., \& Helper, S. (1998). Determinants of trust in supplier relations: Evidence from the automotive industry in Japan and the United States. Journal of Economic Behavior and Organization, 34(3), 387-417. https://doi.org/10.1016/S0167-2681(97)00082-6

Smelser, N. J., \& Swedberg, R. (1994). The sociological perspective on the economy. In Smelser, N. J., \& Swedberg, R. (Ed.), The Handbook of Economic Sociology. Princeton: Princeton University Press. https://doi.org/10.1515/9781400845354-006

Tadelis, S., \& Williamson, O. E. (2013). Transaction Cost Economics. in: Gibbons, R.; Roberts, J. (Ed.). The Handbook of Organizational Economics. Princeton: Princeton University Press.

Williamson, O. (1985). The economic institutions of capitalism: firms, markets, relational contracting. New York, NY: The Free Press.

Williamson, O. (1991). Comparative economic organization: the analysis of discrete structural alternatives. Administrative Science Quarterly, 36(2), 269-296. https://doi.org/10.2307/2393356

Williamson, O. E. (1975). Markets and hierarchies: analysis and antitrust implications. New York, NY: The Free Press.

Williamson, O. E. (1979). Transaction cost economics: the governance of contractual relations. The journal of laws and economics, 22(2), 233-261. https://doi.org/10.1086/466942

Williamson, O. E. (1993). Opportunism and its critics. Managerial and decision economics, 14, 97-107. https://doi.org/10.1002/mde.4090140203

Williamson, O. E. (1996). The mechanisms of governance. New York, NY: Oxford University Press.

Williamson, O. E. (2012). As instituições econômicas do capitalismo: firmas, mercados e relações contratuais. São Paulo, SP: Pezco Editora.

Zylbersztajn, D. (2005). Papel dos Contratos na Coordenação Agro-Industrial: um olhar além dos mercados. Revista de Economia Rural, 43(3), 385-420. https://doi.org/10.1590/S0103-20032005000300001

Zylbersztajn, D., \& Farina, E. M. M. Q. (2010). Dynamics of network governance: a contribution to the study of complex forms. REAd. Revista Eletrônica de Administração, 16(1), 1-19.

\section{Notes}

Note 1 . According to the NIE, transaction is defined by the relations between agents in order to keep the economic system running.

Note 2. According to Fairtrade International (2019), the Fairtrade certification has as main objective the establishment of direct contact between producer and buyer, reducing possible bureaucracies, dependencies and instabilities in the global commodities market, being guided by principles such as transparency, lasting relationship, fair price and respect for standards and the environment.

\section{Copyrights}

Copyright for this article is retained by the author(s), with first publication rights granted to the journal.

This is an open-access article distributed under the terms and conditions of the Creative Commons Attribution license which permits unrestricted use, distribution, and reproduction in any medium, provided the original work is properly cited. 